\title{
Do Democratic Economies Grow Faster? The Case of Asia vs. the EU
}

\author{
Samuel D. Barrows ${ }^{1}$ \\ 1 Senior Lecturer at STEM Business School, Turan University, Kazakhstan, and Doctorate of Business \\ Administration Candidate, Toulouse Business School, France
}

Correspondence: Samuel D. Barrows. Email: sam_barrows@yahoo.com

Received: December 4, 2017

doi:10.5539/ass.v14n2p115

\author{
Accepted: December 26, 2017 Online Published: January 29, 2018 \\ URL: https://doi.org/10.5539/ass.v14n2p115
}

\begin{abstract}
The dynamics of the five fastest growing GDP per capita economies in Asia and the EU are studied between 2010 and 2014. This time frame was selected in order to avoid the height of the 2008-2009 financial crisis, but to include the stimulus and recovery periods which occurred afterward. The intent was not to compare the recoveries or the impact of the stimulus programs. The intent was to compare the economic growth rates of the two groups and also the absolute per capita income along with five topic areas on economies including: configuration, utilization, investments, demographics, and outcomes. A total of twenty measurements are used for assessment from the World Bank databank website. The findings are that the Asian economies grew faster while the EU economies had a higher per capita income. The workforces of the Asia economies are also younger and more flexible whereas the workforces of the EU economies are older, but more educated. Discussions include the links between effective governments and economic development and the links between democracy and economic levels.
\end{abstract}

Keywords: Asia, EU, transition, economies, growth, democracy, institutions

\section{Introduction}

This study compares the economic performance of the five fastest growing economies in Asia with the five fastest growing economies in the EU, based on the GDP per capita growth from 2010 to 2014. The time scale provides for a comparison after the worst of the 2008-2009 financial crisis have been resolved and includes the subsequent stimulus and recovery in both regions. Using 2014 as the close for the study time frame was dictated based on the data provided by the World Bank. Using 2014, as opposed to more recent years, allowed for a more complete country comparison.

The two regions, Asia and the EU, were impacted differently by the crisis. The EU, along with the US, saw more fallout. This was due to the failure in proper regulatory schemes that allowed a "consumption binge in the United States and a few other industrial economies" (Prasad, 2010). This situation was not caused by these developed countries alone. They were partially facilitated and "financed by excess savings in Asia and other emerging market economies" (Prasad, 2010). However, the fallout in Asia was not as severe, due to many firms allowing inventories to be reduced which allowed for ammunition during the recovery which would be used to rebuild inventories ( $\mathrm{Ng}, 2011)$.

To make the comparisons, five areas are studied: economic configuration, economic utilization, investments, demographics, and outcomes. Twenty measurements are taken which fit into these five areas. These measurements are compared between an average of the five countries in Asia and the EU, along with a baseline comparison for the world economy. The data is provided by the World Bank, but some of it originates elsewhere and is fed through the World Bank databank facility. Two retrievals allow for the initial ranking of the countries then for populating the comparison measurements for the selected ranked countries.

The results see the EU countries with older populations and slower economic growth, but higher per capita income. The Asia countries have a younger work force with higher growth rates, but lower per capita income. A discussion is included on institutions and their validity in economic development along with a discussion of certain aspects of the markets relevant to this study topic.

Contributions from the study include the confirmation that effective governments are required for economic development whether they are democratically elected or not (Neale, 1987; Bai \& Wei, 2000; Rodrik, 2000; Fischer, Sahay, \& Vegh, 1996; Selowsky \& Martin, 1997; Berg, Borensztein, Sahay, \& Zettelmeyer, 1999; Moers, 1999; Caballero \& Hammour, 2000; Redek \& Susjan, 2005; Prasad, 2010). There is also confirmation that 
democracy has positive effects on achieving high economic levels (Helliwell, 1994; Rodrik, 2000; Redek \& Susjan, 2005). However, once high economic levels are achieved, growth may slow (Helliwell, 1994).

\section{Literature Review}

\subsection{Institutions}

A country's gross domestic product is based on the productivity of capital and labor and the validity of a country's institutions (Redek \& Susjan, 2005). Hence, institutions form a foundation for a country's economic activity. Depending on the structure and operation of these institutions, this activity can be captive or open to world markets. According to Larry Summers, a country's ability to grow is governed by its ability to integrate into global markets, achieve stability of government funding, and ensure legal rights through its institutions (Summers, 2003). Another economist echoes similar thoughts. "Economic freedom is a broad expression, denoting a well-functioning market economy, an efficient institutional framework, ensuring stability of macroeconomic environment, and enabling efficiency of economic agents" (Redek \& Susjan, 2005).

A functioning market economy includes various levels of efficient state and laissez-faire participations (Rodrik, 2000). Given some control over a state's citizens and economic activity, "the state is in a unique position to provide economic actors with the political foundation of secure markets" (Alston, Eggertsson, \& North, 1996). There are numerous economic models and implementations, but "in the long run countries that have attained high levels of income are those with high quality institutions" (Rodrik, 2006). Institutions include the validity of property rights, legal framework, proper governance, and state norms (Neale, 1987). In addition to functioning stable institutions, "growth is the result of an interplay between capital accumulation, human capital accumulation, productivity growth, technological progress" (Redek \& Susjan, 2005).

Once entrance to markets occurs, measures can be enacted that contribute to growth. Growth is encouraged using a step by step relaxation of economic constraints (Rodrik, 2006). "The speed and the quality" of institutional reforms have been valid predictors of economic performance in transition economies (Redek \& Susjan, 2005). The key is to start with the biggest impediment to investment (Hausmann, Rodrik, \& Velasco, 2005). There is a causal relationship between institutional reform and economic performance. "Institutions do affect economic performance in transition economies" (Redek \& Susjan, 2005).

There may be debate on which are the most important institutions, but in the simplest terms, they include just three items. The valid institutions include stable legal and financial systems plus "a sound and uncorrupt government" (Redek \& Susjan, 2005). "Bureaucratic corruption translates into reduced ability by the government to collect tax revenue" (Bai \& Wei, 2000). Funding of services provided by government is one of its most basic functions. "As long as the government needs the revenue for public goods provision, it would have to rely more on capital control/financial repression" (Bai \& Wei, 2000). This capital control can vary by country, but at a minimum it must provide the funding for most urgent of government services. The "more corrupt countries are indeed more likely to impose capital controls" and the premature reduction of these controls may reduce economic efficiency rather than help it (Bai \& Wei, 2000).

Benchmarking studies in various countries with regard to their institutions have given a variety of results. With this in mind, there are numerous measurements that could be used to assess the various countries. However, "there does not exist a consensus on the theoretical framework to guide empirical work on growth" (Redek \& Susjan, 2005). The G20 has seen divergent views representing the developed markets and emerging markets (Prasad, 2010). There are two main positions. "Some countries would like goals to be defined mainly on the basis of policy variables fiscal balances and regulatory policies while others think that outcome variables current account balances--should be included in the framework" (Prasad, 2010).

\subsection{Institutional Studies}

State institutional involvement is the foundation necessary to attract capital. On a priority basis, the lack of "only war and inflation seem to have been relatively more important for growth performance in transition countries than institutions" (Moers, 1999). A study evaluating the years 1989 through 1997 and looking at twenty six transition economies found that structural reforms were of paramount importance, even above macroeconomic variables, though they initially had a detrimental influence which was more than overcome in subsequent years (Berg et al., 1999).

Another study looked at twenty four transition economies from 1995 through 2002 and "the results reveal that institutional quality does have a robust relationship with economic performance" (Redek \& Susjan, 2005). The outcome is not opaque. The results "revealed clear evidence that institutional development affects economic performance", including curbing inflation, attracting investment, and increasing industrial output (Redek \& 
Susjan, 2005). The study focused on transition economies as opposed to fully developed economies. Economies in transition are involved with coordinating institutional change necessary for economic development required in capitalism (Redek \& Susjan, 2005). One of the takeaways from the study is the need for secure markets. Without secure markets, established economic analysis is not valid in transition economies (Alston, et al., 1996; Redek \& Susjan, 2005).

There is a study that evaluated institution effectiveness areas including regulatory, macroeconomic stabilization, social insurance and conflict management then concluded that higher economic growth is a function of the quality of a country's institutions (Rodrik, 2000). Good stable institutions are a necessary foundation for economic growth, including growth in developing countries, but to build stable institutions takes time (Redek \& Susjan, 2005). The quality of a country's bureaucracy is also be a contributing factor of economic policies (Bai $\&$ Wei, 2000).

These institutions and their controls ensure for government funding and its involvement in the process of business activity and job creation. There is "persistent gross job creation and destruction flows exhibited by all market economies" (Caballero \& Hammour, 2000). With regard to economic growth, it is not usually a smooth evolution. The dynamic of these job movements is step by step, not always one big transformation and whether or not "creative destruction is a core mechanism of economic growth, obstacles to this process are likely to be obstacles to development" (Caballero \& Hammour, 2000). A study looking at the years 1990 through 1995 at the functioning of twenty five transitions found that state institutions were required for foreign direct investments (Moers, 1999).

Additionally, a study which focused on GDP and inflation examined the 1989 through 1994 period for twenty six transition economies in Eastern Europe, the Former Soviet Union, and Mongolia, found that countries which put in deeper reforms grew faster (Fischer, et al., 1996). However, there was a time delay after making these reforms. After a two-year inflation stabilization period, growth resumed, hence the reduction of inflation "appears to be a precondition for growth" (Fischer et al., 1996).

Finally, another study looking at countries in the Former Soviet Union and in Eastern Europe deduced "that fast stabilization, liberalization, and privatization bring benefits earlier" (Selowsky \& Martin, 1997). Laying the foundation earlier can provide the framework of stability where development can progress. Subsequently, "growth will be determined more by physical- and human- capital accumulation" (Selowsky \& Martin, 1997). This has implications for the longer term. "Domestic investment rates and the ability of countries to attract foreign direct investment (with embodied technical change) will become the main source of growth" (Selowsky \& Martin, 1997).

\subsection{Markets}

The 2008-2009 financial crisis had significant adverse impacts on most world markets and most economies, whether developed or emerging. By 2009, the world markets were in trouble, but strong stimulus and fiscal action set the foundation for a measured recovery (Prasad, 2010). These stimulus programs had a significant impact. The emerging market economies bounced back quickly after the crisis (Prasad, 2010). However, the rebound was not evenly spread over all sectors or over all regions. After the crisis, industrial production bounced back, but job growth lagged (Prasad, 2010). It is noteworthy that the causes of the crisis came from the US and Europe, the same locations from which voices for fiscal restraint and regulatory reform usually originate. The 2008-2009 financial crisis was caused by "weak regulatory systems and regulatory failures" plus excess spending in the US and excess savings in Asia which compounded the situation (Prasad, 2010).

Since the crisis, all transition economies have been impacted (Bensidoun, Lemoine, \& Unal, 2009). As the world markets have evolved, participation from more countries are now included. Many emerging economies are now substantially more involved in economic growth and international markets (Lemoine \& Unal-Kesenci, 2007). Transition economies with growth potential generally have a cheap source of labor, the ability to implement new technology, economic liberalization, and market reforms (Bensidoun, et al., 2009). However, cost competition on products can lead to wage pressure of unskilled workers which can create social tension (Gaulier, Lemoine, \& Unal-Kesenci, 2007).

These pressures can arise in numerous ways. "Labor markets have a wide range of characteristics that influence trade flows and both capital and labor mobility" (Ehrenberg, 1994). The interaction of these qualities can generate various configurations. Therefore, "these characteristics will also influence the pace at which economic integration proceeds" (Ehrenberg, 1994). Countries with high growth rates and high unemployment rates imply that growth can be sustainable due to the ability to easily bring more employees into the economy (Penkar \& Deo, 2010). And a sustained growth in employment can be attributed to a country's economic growth (Lu, Fan, 
\& Yan, 2002).

Many emerging economies have found it more effective "to create production capacities in new sectors than to renovate traditional industries burdened with old capital equipment and often located in highly regulated sectors" (Bensidoun et al., 2009). An economy based in manufacturing can more easily tax producers not only because they can be more easily identified, but also the output are more easily measured (Van Der Hoek, 2004). "A strong manufacturing sector is also necessary to cater to the domestic market and avoid the risk of inflation and of balance of payment deficit" (Bensidoun et al., 2009). However, "it is interesting to note that for the industrialized countries, the overwhelming proportion of GDP comes from the services sector" (Penkar, 2010).

The services industry "has always been the strongest in absorbing labor...., due to its higher employment elasticity" (Lu et al., 2002). This phenomena is not limited to one region. This is true worldwide. In both developed and developing economies, expansion of the services industry sees an increase of women to the labor markets and "has become the major job creator" (Lu et al., 2002). However, integration in the world markets and cost advantages will have impact only up to a point. The differences in living standards which provided much of the benefit for integration, may also limit further integration as richer nations may demand increased compliance to stricter standards from developing countries (Ehrenberg, 1994).

\section{$2.4 E U$}

Countries which are closer to market economies perform better (Van Der Hoek, 2004). This is most apparent in the EU and the economic transition of the adjacent countries as they joined the EU. This is "a phenomenon that has marked the development of the bigger part of Europe in the past decade" (Redek \& Susjan, 2005). The EU competitiveness assures higher levels of foreign direct investments to its members (Kuznetsova \& Tarabukina, 2014). In addition, the new economies of the EU have participated in the implementation of market reforms, social programs, and tax-restructuring (Van Der Hoek, 2004). The EU block is competing primarily with the big players, that is the US and Asia (Japan, China, and others) in the world market place (Kuznetsova \& Tarabukina, 2014).

Membership in the EU not only provides a framework for stability, but provides more specifically for the items such as taxes, budgets, interest rates, and debt, which enforce this stability (Van Der Hoek, 2004). The enlargement of the EU saw economies in Eastern Europe take advantage of this phenomena and attract investment capital. In addition, "Eastern Europe and the Baltic States made considerable progress with privatization" (Van Der Hoek, 2004). "The expectation that the countries with less gap to close would adjust faster to the demands of market coordination was fulfilled" (Redek \& Susjan, 2005).

In relation to other emerging economies in the Former Soviet Union and South Eastern Europe, "Central and Eastern European countries have managed the transition better" (Van Der Hoek, 2004). With regard to Foreign Direct Investment (FDI) in Estonia, Latvia, and Lithuania, they "have had large FDI inflows, which is surely due to a good legal system and private property protection" (Redek \& Susjan, 2005). In the long run, democracy is seen as conducive to a country's market growth (Rodrik, 2000). In a study of twenty four transition economies from 1995 through 2002, Estonia, Latvia, and Lithuania "had the best institutional characteristics" and also "had highest growth rates or high GDP levels" (Redek \& Susjan, 2005).

"The quality of the legal system, the protection of private property rights, the structure and stability of the financial system, and a modest and supporting state will contribute to a stable and high long-run economic growth" (Redek \& Susjan, 2005). A study conducted on 125 countries from 1960 to 1985 stated "effects of income on democracy are found to be robust and positive" (Helliwell, 1994). Much of the data reveals relationships between institutions and GDP per capita, one "obvious pattern the better the institutional quality ..., the higher the GDPpc" (Redek \& Susjan, 2005).

The level of income affects democracy and the higher the income, the more likely a well-functioning democracy (Helliwell, 1994). The EU countries prefer more market regulation compared to say the US (Prasad, 2010). Estonia, Latvia, and Lithuania, specifically, used price liberalization and privatization along reductions in government size and subsidies (Redek \& Susjan, 2005). Moreover, democracy has a positive impact on investment and education (Helliwell, 1994).

Once a high level of GDP per capita has been achieved, however, things change somewhat. Subsequent levels of high growth are not necessarily expected. GDP per capita growth is inversely related to high income levels (Helliwell, 1994). Growth not only slows, but can become negative. With regards to the effect on growth related to democracy, "the estimated partial effect of democracy on subsequent economic growth negative but insignificant" (Helliwell, 1994). 
After the 2008-2009 financial crisis, the world achieved a reboot with some economies moving forward after the reset. However, after the crisis, the Eastern Europe economies were "in the doldrums" (Prasad, 2010). The EU situation was felt at home and abroad. The EU debt crisis posed an issue for global demand which slowed manufacturing and exports in economies with that focus (Das, 2012). Despite this fact, "advanced economies have suffered the most damage from the global financial crisis" (Ng, 2011).

\subsection{Asia}

The vast majority of economies in Asia have seen tremendous development since 1980 (Rodrik, 2006). However, there is not "an autonomous engine for the region's trade, as Asia still depends on outside markets for its final goods exports" (Gaulier, et al., 2007). Previously, "some of the most rapidly growing Asian countries have had high tariff barriers on trade" (Rodrik, 2006). However, the Asian countries now see the benefits of working toward a free trade area (Southeast Asian Affairs, 1998).

"Asian trade is increasingly driven by the international segmentation of production processes within the region" (Gaulier, et al., 2007). Because of this, the results of economic growth in Asia allowed governments there to grant more trade liberalization (Rodrik, 2006). In addition to increasing regional trade, the Asian countries see the free trade area as a requirement to counter the trade arrangements by the EU and NAFTA countries (Southeast Asian Affairs, 1998)

China opened its doors to the world in 1978 and has built its economy based on manufacturing (Bensidoun, et al., 2009). "China's emergence in world trade is inseparable of changes in the way industrial production is organised internationally" (Gaulier, et al., 2007). China's exports have been the world's "engine of growth" (Bensidoun, et al., 2009). However, due to weak local demand, "China still needs exports to generate jobs and sell the surplus output" (Prasad, 2010).

The majority of China's FDI inflows are directed to the manufacturing sector and are focused on the assembly of components imported from other countries in Asia (Bensidoun, et al., 2009). "The bulk of inputs that China imports for re-export comes from East Asia, as production moved mainly from East Asian advanced economies to the mainland" (Gaulier, et al., 2007). Currently, the majority of China trade is assembling imported goods for further export, known as "processing trade" (Bensidoun, et al., 2009). "A growth potential exists in service sector in China" (Penkar \& Deo, 2010). China's service sector is growing mainly because of merchandise trade and transport of its manufactured goods (Lemoine \& Unal-Kesenci, 2007). The supply of intermediate goods to processing facilities in China has driven the expansion of East Asian trade with China" (Gaulier, et al., 2007).

During the 2008-2009 financial crisis, Asian firms began reducing their inventories and by 2010, many firms had diminished inventory levels, so when confidence grew in the market place, firms started rebuilding their inventories again $(\mathrm{Ng}, 2011)$. In Southeast Asia, the stimulus programs enacted after the crisis were focused on middle income populations through infrastructure projects and measures to increase consumption (Das, 2012). In Asia, sales, production, domestic demand, and capital inflows increased in 2010, suggesting a recovery ( $\mathrm{Ng}$, 2011). Asian governments then looked to curb inflation and started tightening the money supply which reduced economic growth (Das, 2012). "Financial vulnerability in the Southeast Asian countries remained low as most countries maintained healthy fiscal balances and low levels of external debt" $(\mathrm{Ng}, 2011)$.

In 2010 and 2011, Southeast Asia saw exports grow and member countries realized increased income and consumption (Das, 2012). In the Asian economies, governments spent money on "housing, education, and health" with the effect of "boosting household consumption" (Ng, 2011). For instance, Cambodia saw exports grow in garments and tourism while Lao PDR saw exports grow in precious minerals and "hydropower" (Das, 2012). In addition, the Asian region's banks were stable with very little impact from the debt crisis experienced elsewhere (Ng, 2011).

\section{Methodology}

The intent of this article is to make quantifiable comparisons and confirm previously researched cause and effect relationships between various aspects of national economies. In order to do this, five sections are created which provide insight into the two five country groups from the two regions. These sections are: economic configuration, economic utilization, investments, demographics, and the outcomes derived from these inputs and other factors. The subsequent twenty measurements in these five areas are compared between the two five country groups from Asia, the European Union, and a baseline measurement for the world economy.

The data collected for this article is quantitative in nature and is provided by the World Bank. The World Bank provides extensive economic and demographic data grouped by country and aggregated into various regions. The data measurements provided are on an annual basis. The data used in this study is provided by the World Bank 
website, but a portion originates elsewhere including from: the Organization for Economic Cooperation and Development; United Nations; Eurostat; various national statistics offices; US Census Bureau; Secretariat of the Pacific Community; World Health Organization; International Labour Organization; International Monetary Fund (World Bank, 2017).

The study time frame is from 2010 through 2014. This allows for most of the fallout from the 2008-2009 financial crisis to be stabilized and allows for the regional growth trends and national economic characteristics to be studied. The database called World Development Indicators is selected as well as all countries. The series GDP per capita (current US\$) is selected for the years 2010 and 2014. There are two retrievals from this database. The first retrieval is used to rank the GDP per capita growth between 2010 and 2014. The top five countries are chosen in Asia and in the European Union. Table 1 in the Appendix includes the results from this retrieval for Asia and the European Union. Based on the results, the following countries are selected: Turkmenistan, Lao PDR, China, Mongolia, and Vietnam in Asia; and Latvia, Lithuania, Estonia, Malta, Romania in the European Union; plus a comparative entry for the World. The government type is also listed in Table 1 (CIA, 2017). The twenty measurements are then selected for the years 2010 and 2014 and included in the subsequent tables.

\section{Results}

\subsection{Configuration}

The first group of items is the configuration series. Table 2 in the Appendix displays these items. Agriculture, Industry, and Services are the three sectors, commonly known as the primary, secondary, and tertiary sectors of the economy. Together, these three add to $100 \%$ and thus represent the entire economic sphere. The agriculture mean for the World is at $3.92 \%$ while the EU5 is at 3.76\%. The agriculture mean for the Asia5 is at $16.69 \%$ or more than four times greater than either the World reading or the EU5 reading. With regard to the configuration of the economies, the Asia5 has more flexibility in that they can transfer agriculture labor to other sectors, initially to the manufacturing sector which due to cheap labor costs, they have a built-in advantage over other locations. A country's "agricultural labor force typically shows hidden unemployment which could be released primarily to the industrial sector" (Penkar \& Deo, 2010).

The Industry sector, also known as the industrial sector or the manufacturing sector for the World and the EU5 are fairly comparable at $28.47 \%$, and $27.82 \%$, respectively. The Asia 5 reading is at $38.75 \%$ which is more than $35 \%$ higher than either of the World or the EU5. This is not surprising given that cheap labor provides an advantage to Asia manufacturers. This also helps with government receipts, as these can be tracked more easily as manufacturing output is more easily quantified as opposed to the services sector (Van Der Hoek, 2004).

The services sector is more than $50 \%$ higher in the World and the EU5 compared to the Asia5. As discussed previously in section 4.1, there is the potential of agriculture labor moving to the manufacturing sector. There also exists the possibility of services becoming a larger sector in the Asian economies (Penkar \& Deo, 2010). For future development, the Asia5 has the potential benefits of moving labor to other sectors to take advantage of changes in the market place. Historically, the services industry "has always been the strongest in absorbing labor" (Lu, et al., 2002).

\subsection{Utilization}

The utilization measurements include education, unemployment, employment in agriculture, and total natural resources rents. Table 3 in the Appendix displays these items. The education level for the World and the Asia5 are similar at 9.00 and 9.08 years, respectively, while the EU5 reading is one year higher at 10.00 . The intent was to make a more detailed analysis between primary, secondary, and tertiary levels, but the World Bank data on education metrics is not extensive enough with missing completion data which limited its use for comparative purposes.

Unemployment for the World is at 5.95\% while in the Asia5 it is $4.92 \%$, and the EU5 it is $10.56 \%$. During the study time frame, the Asian economies saw stimulus focused on infrastructure and consumption (Das, 2012). These actions helped keep the unemployment numbers low through the study time frame. Meanwhile, the banking crisis in Europe saw the slowdown of demand which impacted the unemployment numbers there (Das, 2012).

The percentage of employment in agriculture for the World is $29.41 \%$, while for the Asia5 it is $37.26 \%$, and for the EU5 it is $10.41 \%$. As discussed in section 4.1 on configuration, the potential exists for movement from agriculture to other sectors which could be a more effective deployment of labor. Also, technology implementation could allow agriculture labor to be further reduced in both the World and the Asia5.

Some Asian countries are blessed with natural resources. Usually oil and gas, or iron ore come to mind when 
natural resources are discussed. The region also includes precious minerals and "hydropower" (Das, 2012). If managed properly, natural resources can provide a benefit to national economies, not only for exports, but for local demand as well. The Asia5 has $17.88 \%$ of their GDP classified as natural resources. This compares favorably to the World at $3.96 \%$ and the EU5 at a paltry $0.91 \%$.

\subsection{Investments}

Measurements related to investments are located in Table 4 in the Appendix. Gross savings as a percentage of GDP of the Asia5 are 22\% greater than for the World and 34\% greater than the EU5. Personal remittances for the EU5 are $47 \%$ higher than in the Asia5 and are 339\% higher than the World reading. The inference is that remittances are being sent home by EU5 workers from other EU countries. FDI for the Asia5 is $264 \%$ greater than the World reading while the FDI for the Euro5 is 360\% greater than the World reading. With regard to research and development (R\&D) expenditures, the Asia5 and EU5 are 55\% and 56\%, respectively, below the World reading. Central government debt is also lower with the Asia5 and EU5 at $46 \%$ and $52 \%$, respectively, below the World reading.

\subsection{Demographics}

Measurements related to demographics are located in Table 5 in the Appendix. The Gross National Income (GNI) per capita for the Asia5 is $65 \%$ below the World reading while the GNI for the EU5 is $48 \%$ higher than the World reading. When compared to each other, the EU5 reading is $325 \%$ greater than the Asia5 reading. With regard to the population over 64 years of age, the Asia 5 reading is 35\% below the World reading while the EU5 is $116 \%$ above the World reading. The EU5 reading is $229 \%$ greater than the Asia5 reading. Healthcare costs for Asia5 are $58 \%$ less than the World mark while the EU5 are $31 \%$ less than the World reading.

\subsection{Outcomes}

The measurements related to outcomes are located in Table 6 in the Appendix. The external balance on goods and services show that only Asia5 has a negative reading of $-1.23 \%$, signifying a negative external balance, meaning more imports than exports. The Asia5 reading is influenced by the considerably high negative readings for Mongolia. The World and EU5 readings are both positive at $0.53 \%$ and $0.42 \%$, respectively. The current account balance for Asia5 is also negative at $-7.35 \%$ while the EU5 is also negative at $-0.62 \%$. This reflects the fact that more investments are coming into the countries. The Asia5 reading is also influenced by the considerably high negative readings for Mongolia. As expected, inflation is higher in Asia5 at $8.62 \%$ while the World at EU5 readings are at 3.55\% and $2.90 \%$, respectively. The GDP per capita growth per year average for the study time frame is $7.54 \%$ for the Asia 5 while the EU5 sees it at $3.66 \%$, and for the World it is $1.85 \%$. This measurement is an average of the five annual readings for 2010 through 2014 and is a slightly different calculation than the initial ranking which used the 2010 and 2014 years to calculate the overall gains.

\section{Discussion}

With regard to the economic configurations, the Asia5 has the advantage since they have the potential to move labor from low value areas to higher value areas, i.e., from agriculture to manufacturing and from manufacturing to services. The EU5 does not have this same flexibility and can probably only move from manufacturing to services. Utilization measurements see the Asia5 with lower unemployment rates and higher natural resources rents. Both of these measurements indicate higher economic productivity. Investment measurements see the Asia5 with higher gross savings rates, while the EU5 sees higher personal remittances, higher FDI, and lower government debt.

The demographic measurements see the EU5 with substantially higher per capita income, with negative population growth, and a much higher percentage of population over 64 years of age along with a higher healthcare expenditure. The Asia 5 sees much lower per capita income, with higher population growth and much lower percentage of elderly along with a smaller healthcare cost. In the outcomes measurements, the Asia5 has higher inflation and a per capita growth more than double that of the EU5. The EU5 has a low inflation and per capita growth that is less than half that of the Asia5.

The EU5 measurements point to an older population in economies with slower growth, but much higher per capita income. The recent inclusion of these five countries to the EU has had a positive effect on the level of income and their demographics are similar to other EU countries in that there is slower economic growth with an aging population. There are studies indicating that countries closer to market economies or trading block member states seeing improved economic performance (Van Der Hoek, 2004; Kuznetsova \& Tarabukina, 2014). Studies also point to democracy raising GDP per capita levels (Helliwell, 1994; Rodrik, 2000; Redek \& Susjan, 2005). In addition, studies indicate implementation of reforms earlier bring earlier gains (Fischer, et al., 1996; 
Selowsky \& Martin, 1997; Berg, et al., 1999; Moers, 1999).

The Asia5 measurements indicate a younger, more vibrant labor source in countries that are in transition from recent agrarian economies to those with growing industrial and services sectors. High savings rates and high level of natural resource utilization add more advantages as do the high growth per capita. There are studies that discuss the benefits and issues of cheap labor (Ehrenberg, 1994; Lu, et al., 2002; Gaulier, et al., 2007; Bensidoun, et al., 2009; Penkar \& Deo, 2010). There are also studies which indicate the requirement of government's ability to perform its basic functions in order to foster economic development (Neale, 1987; Bai \& Wei, 2000; Rodrik, 2000; Fischer, et al., 1996; Selowsky \& Martin, 1997; Berg, et al., 1999; Moers, 1999; Caballero \& Hammour, 2000; Redek \& Susjan, 2005; Prasad, 2010).

\section{Conclusion}

The intent of this study was to compare the five fastest growing economies in Asia and the European Union. Economies worldwide were affected by the 2008-2009 financial crisis. To some extent, this study also assessed how the various regions made strides to adjust their economies to the circumstances during the crisis and more importantly during the five years after the crisis. It seems that the five countries in Asia rebounded better than the five countries in the EU. Given the vastly different cost structures and capabilities, low cost manufacturing in economies staffed by younger, less-expensive workers has benefits that are hard to match.

The title of the study asks the question: do democratic economies grow faster? There are studies that quantify the value of democracy and its effect on economic development (Helliwell, 1994; Rodrik, 2000; Redek \& Susjan, 2005). However, once a certain level of economic development occurs, growth will naturally slow (Helliwell, 1994). Whether or not a country is a democracy, there still exists the need for a valid, active government to foster and ensure sustained development (Neale, 1987; Bai \& Wei, 2000; Rodrik, 2000; Fischer, et al., 1996; Selowsky \& Martin, 1997; Berg, 1999; Moers, 1999; Caballero \& Hammour, 2000; Redek \& Susjan, 2005; Prasad, 2010).

What is apparent is that growth is certainly higher in developing economies where there is a cost advantage, primarily in labor, but also with other resources such as land, materials, energy, and proximity to related markets. These economies will continue with higher growth until the cost structures change enough to reduce the advantage they have over other more mature economies. The answer to the question is that democratic economies may not grow faster, but the economic level enjoyed by their citizens is typically higher than those countries without democracy.

\section{References}

Alston, L. J., Eggertsson, T., \& North, D. C. (1996). Empirical Studies in Institutional Change. Cambridge University Press. https://doi.org/10.1017/CBO9781139174633

Bai, C. E., \& Wei, S. J. (2000). Quality of Bureaucracy and Open-Economy Macro Policies. NBER working paper no. 7766, 2000. Retrieved November 11, 2017, from http://www.nber.org/papers/w7766

Bensidoun, I., Lemoine, F., \& Unal, D. (2009). The Integration of China and India into the World Economy: A Comparison. The European J. of Comparative Economics, 6(1), 131. Retrieved December 1, 2017, from https://www.questia.com/library/journal/1G1-214205373/the-integration-of-china-and-india-into-the-world

Berg, A., Borensztein, E., Sahay, R., \& Zettelmeyer, J. (1999). The Evolution of Output in Transition Economies: Explaining the Differences. IMF research paper, May 1999. Retrieved December 1, 2017, from https://www.imf.org/en/Publications/WP/Issues/2016/12/30/The-Evolution-of-Output-in-Transition-Econo mies-Explaining-the-Differences-3084

Caballero, R. J., \& Hammour, M. L. (2000). Creative Destruction and Development: Institutions. Crises, and Restructuring, Working Paper 00-17, August, 2000. https://dx.doi.org/10.2139/ssrn.238248

CIA. (2017). Central Intelligence Agency The World Factbook. Retrieved December 5, 2017 from https://www.cia.gov/library/publications/the-world-factbook/fields/2128.html

Das, S. B. (2012). Southeast Asian Economies: Moderating Growth Momentum. Southeast Asian Affairs, 23. Retrieved November 28, 2017, from https://www.questia.com/article/1P3-2843370731/southeast-asian-eco nomies-moderating-growth-momentum

Ehrenberg, R. G. (1994). Labor Markets and Integrating National Economies. The Brookings Institution, 1994. Retrieved November 29, 2017, from https:/www.questia.com/read/1P3-10373070/labor-markets-and-int egrating-national-economies

Fischer, S., Sahay, R., \& Vegh, C. A. (1996). Stabilization and growth in transition economies: The early 
experience. Journal of Economic Perspectives, 10(2), 45-66. https://dx.doi.org/10.1257/jep.10.2.45

Gaulier, G., Lemoine, F., \& Unal-Kesenci, D. (2007). China's emergence and the reorganisation of trade flows in Asia. China Economic Review, 18(3), 209-43. https://dx.doi.org/10.1016/j.chieco.2007.02.008

Hausmann, R., Rodrik, D., \& Velasco, A. (2005). Growth Diagnostics. Kennedy School of Government, Harvard University, Massachusetts. https://dx.doi.org/10.1093/acprof:oso/9780199534081.003.0015

Helliwell, J. F. (1994). Empirical Linkages between Democracy and Economic Growth. British Journal of Political Science, 24(2), 225-48. https://dx.doi.org/10.1017/S0007123400009790

Kuznetsova, N. V., \& Tarabukina, A. A. (2014). The European Union: It's Place in the World Economy and the Impact on the International Economic Processes. Asian Social Science, 10(15), 230. https://dx.doi.org/10.5539/ass.v10n15p230

Lemoine, F., \& Unal-Kesenci D. (2007). China and India in international trade: from laggards to leaders? CEPII Working Paper, 2007_19, November. Retrieved November 28, 2017, from https://pdfs.semanticscholar.org/ 424b/99e561047927e1a89cb7ba203c9c6c3e934b.pdf

Lu, M., Fan, J., Liu, S., \& Yan, Y. (2002). Employment Restructuring during China's Economic Transition: As in Developed Countries, China's Service Sector Has Become the Main Job Creator, the Country's Labor Force Is Better Educated, and the Average Age of the Employed Is Rising; Driving Those Phenomena Are a Fast-Paced Employment Restructuring and a Growing Private Enterprise at the Expense of State and Collective Ownership. (Employment Restructuring in China). Monthly Labor Review, 125(8), 25. Retrieved November 29, 2017 from https://www.questia.com/read/1G1-95263058/employment-restructuring-duringchina-s-economic-transition

Moers, L. A. (1999). How important are Institutions for Growth and Transition Countries. Retrieved November 27, 2017, from http://papers.tinbergen.nl/99004.pdf

Neale, W. C. (1987). Institutions. Journal of Economic Issues, 21(3), 1177-1206. https://dx.doi.org/10.1080/00213624.1987.11504700

$\mathrm{Ng}$, T. H. (2011). Southeast Asian Economies in 2010: The Challenge of Sustaining Growth after the Recovery. Southeast Asian Affairs, 3. Retrieved November 30, 2017 from https://www.questia.com/article/1P32602089431/southeast-asian-economies-in-2010-the-challenge-of

Penkar, S., \& Deo, P. (2010). A Study of the Financial Characteristics of Firms in Two Rapidly Growing Economies. Journal of International Business Research, 9(2), 117. Retrieved November 29, 2017, from https://www.questia.com/library/journal/1G1-241946063/a-study-of-the-financial-characteristics-of-firms

Prasad, E. (2010). The World Economy: Bottoming out or a Respite before the Next Crunch? The Cato Journal, 30(2), 383. Retrieved November 28, 2017, from https://www.questia.com/library/journal/1G1-228509092/ the-world-economy-bottoming-out-or-a-respite-before

Redek, T., \& Susjan, A. (2005). The Impact of Institutions on Economic Growth: The Case of Transition Economies. J. of Economic Issues, 39(4), 995-1027. https://dx.doi.org/10.1080/00213624.2005.11506864

Rodrik, D. (2000). Institutions for High Quality Growth: What They Are and How to Acquire Them. Studies in Comparative International Development, 35(3), 3-31. https://dx.doi.org/10.1007/BF02699764

Rodrik, D. (2006). Development Lessons for Asia from Non-Asian Countries. Asian Development Review, 23(1), 1. Retrieved November 28, 2017, from https://www.questia.com/article/1P3-1145372941/developmentlessons-for-asia-from-non-asian-countries

Selowsky, M., \& Martin, R. (1997). Policy Performance and Output Growth in the Transition Economies. The American Economic Review, 87(2), 349-353. Retrieved November 27, 2017, from http://cc10.aubg.bg/faculty/Didar/ECON\%20402/PolicyGrowthTransitionalEconomies.pdf

Southeast Asian Affairs. (1998). Rejuvenated East Asian Regionalism. Retrieved November 28, 2017, from https://www.questia.com/article/1P3-972490811/rejuvenated-east-asian-regionalism

Summers, L. (2003). Godkin Lectures. John F. Kennedy School of Government, Harvard Uni. Massachusetts.

Van Der Hoek, M. P. (2004). The European Union: Eastern Enlargement and Taxation. Atlantic Economic Journal, 32(2), 75. https://dx.doi.org/10.1007/BF02298826

World Bank. (2017). The World Bank DataBank World Development Indicators. Retrieved November 1, 2017, from http://databank.worldbank.org/data/reports.aspx?source=world-development-indicators\#? 


\section{Appendix}

Table 1.

\begin{tabular}{|c|c|c|c|c|c|}
\hline \multicolumn{6}{|c|}{ Top 5 GDP per capita growth by region } \\
\hline Region & Country & 2010 & 2014 & Increase & Government type \\
\hline Asia & Turkmenistan & 4,439 & 7,962 & $79 \%$ & Presidential Republic, Authoritarian \\
\hline Asia & Lao PDR & 1,141 & 2,018 & $77 \%$ & Communist State \\
\hline Asia & China & 4,561 & 7,684 & $68 \%$ & Communist State \\
\hline Asia & Mongolia & 2,650 & 4,182 & $58 \%$ & Semi-Presidential Republic \\
\hline Asia & Vietnam & 1,334 & 2,052 & $54 \%$ & Communist State \\
\hline Asia & Mean & 2,825 & 4,779 & $67 \%$ & NA \\
\hline $\mathrm{EU}$ & Latvia & 11,326 & 15,725 & $39 \%$ & Parliamentary Republic \\
\hline EU & Lithuania & 11,985 & 16,555 & $38 \%$ & Semi-Presidential Republic \\
\hline $\mathrm{EU}$ & Estonia & 14,639 & 19,941 & $36 \%$ & Parliamentary Republic \\
\hline $\mathrm{EU}$ & Malta & 21,088 & 26,181 & $24 \%$ & Parliamentary Republic \\
\hline EU & Romania & 8,297 & 10,020 & $21 \%$ & Semi-Presidential Republic \\
\hline $\mathrm{EU}$ & Mean & 13,467 & 17,685 & $32 \%$ & NA \\
\hline World & World & 9,509 & 10,850 & $14 \%$ & NA \\
\hline
\end{tabular}

Table 2 .

\begin{tabular}{lccc}
\hline Configuration Measurements (Annual mean) & World & Asia 5 & EU 5 \\
\hline Agriculture, value added (\% of GDP) & 3.92 & 16.69 & 3.76 \\
Industry, value added (\% of GDP) & 28.47 & 38.75 & 27.82 \\
Services, etc., value added (\% of GDP) & 67.60 & 44.56 & 68.42 \\
Total (\% of GDP) & 99.99 & 100.00 & 100.00 \\
\hline
\end{tabular}

Table 3.

\begin{tabular}{lccc}
\hline Utilization Measurements (Annual mean) & World & Asia 5 & EU 5 \\
\hline Compulsory education, duration (years) & 9.00 & 9.08 & 10.00 \\
Unemployment, total (\% of total labor force) & 5.95 & 4.92 & 10.56 \\
Employment in agriculture (\% of total employment) & 29.41 & 37.26 & 10.41 \\
Total natural resources rents (\% of GDP) & 3.96 & 17.88 & 0.91 \\
\hline
\end{tabular}

Table 4.

\begin{tabular}{lccc}
\hline Investment Measurements (Annual mean) & World & Asia 5 & EU 5 \\
\hline Gross savings (\% of GDP) & 24.78 & 30.13 & 22.44 \\
Personal remittances, received (\% of GDP) & 0.67 & 2.02 & 2.97 \\
Foreign direct investment, net inflows (\% of GDP) & 2.66 & 9.68 & 12.23 \\
Research and development expenditure (\% of GDP) & 2.07 & 0.93 & 0.91 \\
Central government debt, total (\% of GDP) & 84.87 & 45.89 & 40.66 \\
\hline
\end{tabular}

Table 5.

\begin{tabular}{lccc}
\hline Demographic Measurements (Annual mean) & World & Asia 5 & EU 5 \\
\hline GNI per capita, Atlas method (current US\$) & 10,287 & 3,578 & 15,212 \\
Population growth (annual \%) & 1.20 & 1.29 & $(0.60)$ \\
Age dependency ratio, old $>$ 64 (\% of working-age population) & 11.99 & 7.85 & 25.86 \\
Health expenditure, total (\% of GDP) & 9.89 & 4.13 & 6.83 \\
\hline
\end{tabular}


Table 6.

\begin{tabular}{lccc}
\hline Outcomes Measurements (Annual mean) & World & Asia 5 & EU 5 \\
\hline External balance on goods and services (\% of GDP) & 0.53 & $(1.23)$ & 0.42 \\
Current account balance (\% of GDP) & $\mathrm{NA}$ & $(7.35)$ & $(0.62)$ \\
Inflation, GDP deflator (annual \%) & 3.55 & 8.62 & 2.90 \\
GDP per capita growth (annual \%) & 1.85 & 7.54 & 3.66 \\
\hline
\end{tabular}

\section{Copyrights}

Copyright for this article is retained by the author(s), with first publication rights granted to the journal.

This is an open-access article distributed under the terms and conditions of the Creative Commons Attribution license (http://creativecommons.org/licenses/by/4.0/). 